УДК 681.513:62-58, DOI 10.31210/visnyk2018.04.32

(C) 2018

Лєві Л. І., доктор технічних наук, професор

Полтавський національний технічний університет імені Юрія Кондратюка

\title{
ЗАСТОСУВАННЯ НЕЙРОННИХ МЕРЕЖ ДЛЯ АВТОМАТИЗОВАНОГО КЕРУВАННЯ ВОЛОГОЗАБЕЗПЕЧЕНІСТЮ СІЛЬСЬКОГОСПОДАРСЬКИХ КУЛЬТУР
}

\section{Рецензент - доктор технічних наук, доцент О. В. Шульга}

Розглянуто нейромережевий підхід до автоматизованого керування вологозабезпеченістю сільськогосподарських культур. Сучасний стан теорії $і$ практики створення штучних нейронних мереж $і$ нейрокомп 'ютерів надав можливість розробки принципово нових алгоритмів і методів керування складними нелінійними динамічними об'єктами. Це дозволяє підвищити точність керування вологістю трунту, забезпечити отримання планових врожаӥв сільськогосподарських культур, економити водні та енергетичні ресурси за рахунок їх раџіонального використання.

Ключові слова: керування вологозабезпеченням сільськогосподарських культур, нейронна мережа, штучний нейрон, послідовна схема керування, паралельна схема керування, схема керування із самоналаштуванням, схема керування з емулятором і контролером.

Постановка проблеми. Проблема керування вологозабезпеченням сільськогосподарських культур у цілому світі $є$ надзвичайно важливою. Перетворення сільськогосподарського виробництва у високорозвинутий сектор економіки неможливе без зменшення його залежності від несприятливих природо-кліматичних умов шляхом ведення зрошуваного землеробства у зонах недостатнього та нестійкого зволоження. Зрошуване землеробство $\epsilon$ важливою складовою виробництва продукції рослинництва, стабілізуючим фактором продовольчого та ресурсного забезпечення держави, особливо в роки 3 несприятливими погодними умовами. В залежності від кліматичних умов, рельєфу, глибини залягання грунтових вод застосовують різні види зрошення: краплинне, дощування, полив по смугам i борознам, підгрунтове. На територіях із надмірним зволоженням для зменшення вологості грунту до необхідного для сільськогосподарських культур рівня застосовують осушувальні системи. На територіях з глибиною залягання грунтових вод до 2 м та рівнинним рельєфом широко застосовують підгрунтове зволоження. Прикладами є західна та центральна частини України,
Білорусь. Осушені землі в Україні становлять 3,2 млн га, майже $70 \%$ із них мають закритий дренаж, на 1,1 млн га застосовується двостороннє регулювання водного режиму. На даний час технічний стан внутрішньогосподарських осушувальних систем потребує покращення шляхом модернізації та докорінної реконструкції. Крім того, через незадовільний технічний стан меліоративної мережі в посушливі роки не на всій площі використовуються за призначенням системи двобічної дії. Існує потреба відновлення ефективного функціонування наявних меліоративних систем на осушуваних землях, що не повною мірою забезпечується шляхом використання ручного режиму регулювання вологості грунту. Існуючі засоби водорегулювання потребують вдосконалення у напрямку покращення точності регулювання рівнів води, врахування впливу випадкових зовнішніх збурень, забезпечення ресурсозберігаючих режимів зрошення сільськогосподарських рослин в умовах дефіциту водних та енергетичних ресурсів, що створить умови для ефективного ведення землеробства.

Аналіз останніх досліджень і публікацій, у яких започатковано розв'язання проблеми. Як відомо, максимальна врожайність сільськогосподарських культур досягається за оптимальної кількості вологи, живлення, тепла, повітря і світла. При цьому необхідний для сільськогосподарських культур водний режим грунту створюється відповідним режимом зрошення, який встановлює норми, терміни і кількості поливів в залежності від біологічних особливостей культур, природних і господарських умов. Під час визначення витрат води на зрошення враховують водоспоживання, або сумарне випаровування, що залежить від кліматичних умов, кількості теплової енергії, яка надходить на поверхню, вологості грунту, виду та врожайності культури. Питання управління водогосподарськомеліоративними об‘єктами у зоні надлишкового та нестійкого зволоження України на рівнях стратегічного та тактичного планування на ос- 


\section{TЕХНІЧНІ НАУКИ}

нові поєднання короткотермінового та довготермінового метеорологічних прогнозів розглядалися у [3]. У [5] розроблено метод управління вологістю грунту на основі багатошарової моделі вологопереносу. Однак залишаються відкритими питання адаптації і самонавчання автоматизованих систем керування вологістю грунту в умовах дії випадкових погодних факторів, зміни характеристик об“єкта керування, підвищення точності керування завдяки оперативному врахуванню дії збурень на об‘єкт, забезпечення отримання планової врожайності сільськогосподарських культур у разі раціонального використання енергетичних і водних ресурсів. Крім того, сучасні системи керування вологозабезпеченістю сільськогосподарських культур повинні не тільки забезпечувати достатню точність керування, а й прогнозувати потребу рослин у воді на певний період, мінімізувати енергетичні та водні витрати без втрати врожаю, бути надійними та зручними в експлуатації, надавати оператору повну та своєчасну інформацію про значення усіх параметрів та стан системи керування. Комплексне вирішення цих проблем можливе лише за допомогою розробки сучасних технічних засобів автоматизації, нових математичних моделей вологопереносу у ненасиченій зоні грунту та методів керування вологозабезпеченістю сільськогосподарських культур. Таким чином, розробка методів автоматизованого керування вологозабезпеченістю сільськогосподарських культур 3 врахуванням збурень $є$ актуальним науковопрактичним завданням.

Метою роботи $\epsilon$ розробка моделей і методів керування вологозабезпеченістю сільськогосподарських культур на осушувально-зволожувальних системах (ОЗС) з підгрунтовим зволоженням для підвищення ефективності функціонування цих систем та забезпечення отримання гарантованих врожаїв сільськогосподарських культур 3 одночасною економією водних та енергетичних ресурсів.

Для досягнення поставленої мети необхідно вирішити наступні задачі:

1. Аналіз існуючих методів керування вологозабезпеченістю сільськогосподарських культур, математичних моделей вологопереносу.

2. Розробка прогнозуючих математичних моделей вологопереносу в ненасиченій зоні модульної ділянки грунту на основі нейронних мереж.

3. Розробка методів керування вологозабезпеченістю сільськогосподарських культур за підгрунтового зволоження 3 врахуванням дії збурень на основі нейронних мереж.
Об‘єктом дослідження є процеси автоматизованого керування вологозабезпеченістю сільськогосподарських культур на ОЗС $з$ підгрунтовим зволоженням.

Предметом дослідження є математичні моделі, методи та системи автоматизованого керування вологозабезпеченістю сільськогосподарських культур у випадку підгрунтового зволоження 3 врахуванням діючих збурень.

Методи дослідження включають моделі та методи нейронних мереж та адаптивного керування складними технічними системами в умовах невизначеності.

Результати дослідження. Нейронні мережі (НМ) являють собою обчислювальні структури для моделювання біологічних процесів, що асоціюються 3 процесами мозку людини [2]. НМ представляють собою системи, здатні до адаптації та навчання шляхом аналізу позитивних і негативних впливів. Елементарним перетворювачем у даних мережах являється штучний нейрон - аналог біологічного нейрону. Сучасний стан теорії і практики створення штучних нейронних мереж (ШНМ) і нейрокомп'ютерів надав можливість розробки принципово нових алгоритмів $\mathrm{i}$ методів керування складними нелінійними динамічними об'єктами. Більшість схем нейромережевого керування засновані на використанні наступних підходів [1, 6, 7].

1. Послідовна схема керування. Якщо позначити відношення «вхід-вихід» для об'єкта керування як $\mathrm{y}=\mathrm{f}(\mathrm{x})$, то НМ реалізує зворотне відображення $\mathrm{u}=\mathrm{f}^{-1}(\mathrm{y})$. Таким чином, якщо подати на НМ опорний сигнал $\mathbf{r}$, то вихідний сигнал об'єкта керування у приймає значення $\mathbf{r}$, тому що $\mathrm{y}=\mathrm{f}(\mathrm{u})=\mathrm{f}\left(\mathrm{f}^{-1}(\mathrm{r})\right)=\mathrm{r}$.

2. Паралельна схема керування. НМ паралельного типу використовується для підлаштування керуючого вхідного сигналу $\mathrm{u}_{1}$, що є вихідним сигналом звичайного ПІД-контролера. Налаштування виконується таким чином, щоб вихідний сигнал об'єкта керування $\mathrm{y}$ як можна точніше відповідав заданому опорному сигналові $\mathrm{r}$.

3. Схема керування із самоналаштуванням. Тут НМ використовується для налаштування параметрів звичайного контролера подібно налаштуванню, виконуваного людиноюоператором.

4. Схема керування $з$ емулятором і контролером. Нейроконтролер навчається на інверсній моделі об'єкта керування, а нейроемулятор - на 


\section{TEХНІЧНІ НАУКИ}

звичайній моделі об'єкта. Нейроконтролер може навчатися безпосередньо на основі зворотного поширення помилки через нейроемулятор.

Для аналізу цих схем нейронного керування розроблені алгоритми навчання НМ і програмні моделі, на яких проводяться дослідження процесів керування динамічними об'єктами. Одним із напрямків застосування ШНМ є прогнозування величин, що змінюються в часі. Характерними ознаками доцільності застосування нейронних мереж до вирішення сформульованої задачі $\epsilon$ такі:

- відсутній алгоритм або невідомі принципи вирішення задач, але накопичено достатню кількість прикладів;

- проблема характеризується великими обсягами вхідної інформації;

- дані неповні або надлишкові, зашумлені, частково суперечливі.

Поряд із цим можна сформулювати прогнозуючі властивості ШНМ, до яких, зокрема, належать такі.

1. Здатність НМ здійснювати багатопараметричний прогноз.

2. Необхідна оперативність прогнозування, що досягається максимальною розпаралеленістю процесу обробки інформації.

3. Нечутливість до недоліків апріорної інформації про динаміку прогнозованого об'єкта.

4. Можливість обробки даних, представлених у різнотипних шкалах.

5. Внаслідок повної зв'язності й великої кількості штучних нейронів, НМ зберігає своїх властивості навіть у випадку руйнування іï окремої частини. Як наслідок, проявляється висока надійність НМ і толерантність результатів прогнозу $\mathrm{Y}_{\mathrm{i}}^{\mathrm{t}+1}$ до перекручувань i перешкод у вхідних векторах $\mathrm{X}_{\mathrm{i}}^{\mathrm{t}+1}$.

6. Здатність до довчання.

7. Можливість прогнозування стрибків і подій, що не спостерігалися раніше в навчальній вибірці спостережуваного об'єкта; може бути вибором або синтезом НМ такого типу, які здатні виробляти прототип й узагальнювати прецеденти по їхній подобі.

На даний момент розроблено методи прогнозування повені у реальному часі на базі нейронних мереж, зокрема в Індії [10]. Методи прогнозування повені у реальному часі на базі статистичних або стохастичних моделей базуються на припущеннях лінійності, хоча кількість поверхневого стоку як результат випадіння опадів залежить від декількох факторів, дана залежність $\epsilon$ нелінійною, тому їі зручно представити на базі НМ. Використання НМ для прогнозування повені у реальному часі знаходиться на етапі розвитку. Підтоплення сільських територій на півдні України є значною соціальною проблемою, що має негативні екологічні та економічні наслідки, вимагає оцінки впливу різних чинників на процеси підтоплення, прогнозування їхнього впливу та прийняття рішень щодо покращення ситуації. Для розв'язання даної задачі запропоновано методику системної оцінки та прогнозування підтоплення територій на основі пересептронних моделей [4]. Дослідження процесів коливання рівня грунтових вод (РГВ) показали, що воно тісно пов'язано із випаданням аномальної та нерівномірної кількості атмосферних опадів. Прогнозування РГВ на основі інформаційної технології дозволяє здійснювати системне управління територією як сукупністю інженерних заходів для запобігання або зменшення шкідливої дії підтоплення, наприклад, визначити необхідність попереджувального ввімкнення дренажних насосних станцій. За допомогою нейронних мереж здійснюється оцінка опадів, річкового стоку та форми хмар за допомогою аналізу супутникового знімку досліджуваної території в Австралії, США, Мексиці та Північній Африці [10]. Проводилося моделювання геофізичних процесів на базі нейронних мереж, зокрема літологічні оцінки та дослідження акустичного опору за допомогою інтеграції сейсмічних і геологічних даних [9]. Нейронні мережі замість методів регресійного аналізу використовуються для виведення педотрансферних функцій, які відображають залежність між основними та гідравлічними властивостями грунтів [8]. Більшість ознак доцільності застосування НМ притаманні О3С, тому НМ можуть бути використані для розробки нових методів керування вологозабезпеченістю сільськогосподарських культур з врахуванням дії збурень.

Висновок. Методи керування вологозабезпеченістю сільськогосподарських культур у разі підгрунтового зволоження на основі НМ 3 оперативним врахуванням випадкових погодних збурень дозволяють підвищити точність керування вологістю грунту, забезпечити отримання планових врожаїв сільськогосподарських культур, економити водні та енергетичні ресурси за рахунок їх раціонального використання, підвищити ефективність функціонування ОЗС та забезпечити іiі незалежність від кліматичних і погодних умов. 


\section{БІБЛІОГРАФІЯ}

1. Комашинский В. И. Нейронные сети и их применение в системах управления и связи / В. И. Комашинский, Д. А. Смирнов. - Москва : Горячая линия - Телеком, 2003. -93 с.

2. Круглов В. В. Нечёткая логика и искусственные нейронне сети / В.В.Круглов, М. И. Дли, Р. Ю. Голунов. - Москва, 2001. - 221 с.

3. Науково-методичні та організаційні засади управління водогосподарсько-меліоративними об‘єктами гумідної зони України за короткотерміновим метеорологічним прогнозом. Методичні рекомендації. / А. М. Рокочинський, Я. Я. Зубик, Л. В. Зубик, С. І. Покладньов ; за участю спеціалістів Держводгоспу України В.А. Сташук, В.Д. Крученюк. - Рівне : НУВГП, 2005. - 53 с.

4. Роде A. A. Основы учения о почвенной влаге. / А. А. Роде. - Л. : Гидрометеоиздат, 1969. T. 2. $-288 \mathrm{c}$.

5. Скрипник О. В. Системы двустороннего регулирования водного режима / О. В. Скрипник //

\section{ANNOTATION}

Lievi L. I. The use of neural networks for the automated management of crop moisture

The highest yield of agricultural crops is achieved with the optimal amount of moisture, nutrition, heat, air and light. At the same time, the water regime of the soil is necessary for crops and is created by the appropriate irrigation regime, which establishes the norms, timing and amount of irrigation depending on the biological characteristics of the crops, natural and economic conditions. In determining the irrigation water flow, water consumption or total evaporation is taken into account, depending on climatic conditions, the amount of thermal energy supplied to the surface, soil moisture, the type and yield of the crop.

Therefore, issues of adaptation and self-study of automated soil moisture management systems under the influence of random weather factors, changes in the characteristics of the control object, improvement of control accuracy due to the operational accounting of the effect of disturbances on the object, ensuring the production of planned crop yields while rational use of energy and water
Гидротехника и мелиорация. - 1984, №4. C. 55-57.

6. Усков А. А. Интеллектуальные технологии управления. Искусственные нейронные сети и нечёткая логика / А. А. Усков, А. В. Кузьмин. Москва : Горячая линия - Телеком, 2004. - 143 с.

7. Юревич Е.И. Теория автоматического управления / Е. И. Юревич. - 3-е изд. - СПб. : БХВ-Петербург, 2007. - 560 с.

8. Pachepsky Y. Development of Pedotransfer Functions in Soil Hydrology / Y. Pachepsky Y., W.J. Rawls. - Amsterdam : Elsevier, 2004. - 512 p.

9. Poulton Mary M. Computational neural networks for geophysical data processing / Mary M. Poulton. - Amsterdam, 2001. - 335 p.

10. Wheater $H$. Hydrological modeling in arid and semi-arid areas / Howard Wheater, Soroosh Sorooshian, K. D. Sharma. - New York : Cambridge University Press, 2008. - 223 p.

resources are relevant.

In addition, modern moisture management systems for agricultural crops should not only ensure sufficient control accuracy, but also predict the plants need for water for a certain period, minimize energy and water costs without yield loss, be reliable and convenient in operation, provide the operator with complete and timely information about the value of all parameters and the state of the control system.

To solve these problems, an approach to automating the process of controlling irrigation systems using neural networks has been considered. The proposed approach allows to improve the accuracy of soil moisture management, to ensure the production of planned crop yields, to save water and energy resources due to their rational use.

Key words: crop moisture management, neural network, artificial neuron, sequential control circuit, parallel control circuit, control circuit with self-adjusting, control circuit with emulator and controller. 